\section{Morphological and Physiological Responses of Cornus alba to Salt and Drought Stresses under Greenhouse Conditions}

\author{
Qiang Liu \\ College of Life Sciences and Technology, Central South University of \\ Forestry and Technology, 498 South Shaoshan Road, Changsha, Hunan \\ 410004, China; and Hunan Academy of Forestry, 658 South Shaoshan Road, \\ Changsha, Hunan 410004, China
}

\section{Youping Sun}

Department of Plants, Soils and Climate, Utah State University, 4820 Old Main Hill, Logan, UT 84322

\section{James Altland}

U.S. Department of Agriculture, Agricultural Research Service, Application Technology Research Unit, 1680 Madison Avenue, Wooster, OH 44691

\section{Genhua Niu}

Texas A\&M AgriLife Research Center at Dallas, Texas A\&M University, 17360 Coit Road, Dallas, TX 75252

Additional index words. drought tolerance, salt tolerance, tatarian dogwood, volumetric water content

\begin{abstract}
Tatarian dogwood (Cornus alba) is an ornamental shrub with white fruits, creamy-white flowers, and red stems in fall through late winter and is widely used in residential landscape, public parks, and botanical gardens. Two greenhouse experiments were conducted to characterize the survival, morphological, aesthetic, and physiological responses of tatarian dogwood seedlings to salinity and drought stresses. In Expt. 1, tatarian dogwood seedlings grown in three soilless growing substrates (Metro-Mix 360, 560 , and 902) were irrigated with a nutrient solution at an electrical conductivity (EC) of $1.2 \mathrm{dS} \cdot \mathrm{m}^{-1}$ (control) or saline solution (by adding calculated amount of sodium chloride and calcium chloride) at an EC of 5.0 or $10.0 \mathrm{dS} \cdot \mathrm{m}^{-1}$ once per week for 8 weeks. Results showed that substrate did not influence the growth of tatarian dogwood seedling. All plants irrigated with saline solutions at an EC of $10.0 \mathrm{dS} \cdot \mathrm{m}^{-1}$ died, whereas those irrigated with saline solutions at an EC of $5.0 \mathrm{dS} \cdot \mathrm{m}^{-1}$ exhibited severe foliar salt damage with an average visual score of 1.0 (on a scale of 0 to 5 , with $0=$ dead and $5=$ excellent without foliar salt damage). Compared with the control, saline solutions at an EC of 5.0 $\mathrm{dS} \cdot \mathrm{m}^{-1}$ reduced plant height and shoot dry weight (DW) by $50.8 \%$ and $55.2 \%$, respectively. Relative chlorophyll content [soil plant analysis development (SPAD) reading], chlorophyll fluorescence $\left(F_{v} / F_{m}\right)$, and net photosynthesis rate $\left(P_{n}\right)$ also decreased when plants were irrigated with saline solutions at an EC of 5.0 and $10.0 \mathrm{dS} \cdot \mathrm{m}^{-1}$. Leaf sodium $\left(\mathrm{Na}^{+}\right)$concentration of tatarian dogwood seedlings irrigated with saline solutions at an EC of 5.0 and $10.0 \mathrm{dS} \cdot \mathrm{m}^{-1}$ increased 11 and 40 times, respectively, compared with the control, whereas chloride $\left(\mathrm{Cl}^{-}\right)$concentration increased 25 and 33 times, respectively. In Expt. 2, tatarian dogwood seedlings were irrigated at a substrate volumetric water contents (volume of water/volume of substrate, VWC) of $15 \%, 20 \%$, $25 \%, 30 \%, 35 \%, 40 \%$, or $45 \%$ using a sensor-based automated irrigation system for 60 days. Results showed that drought stress decreased plant growth of tatarian dogwood seedlings with a reduction of $71 \%, 85 \%$, and $87 \%$ in plant height, leaf area, and shoot DW, respectively, when VWC decreased from $45 \%$ to $15 \%$, but all plants survived at all VWC treatments. Significant reductions of photosynthesis $\left(P_{n}\right)$, stomatal conductance $\left(g_{S}\right)$, transpiration rate $(E)$, and water potential were also found in plants at a $\mathrm{VWC}$ of $15 \%$, compared with other VWCs. However, SPAD readings and $F_{v} / F_{m}$ of tatarian $\operatorname{dog}$ oood seedlings were similar among the VWCs. In conclusion, tatarian dogwood seedlings were sensitive to the salinity levels tested in this study but could survive at all tested substrate volumetric water contents and exhibited resistance to drought conditions.
\end{abstract}

Water scarcity is one of the severe environmental constraints to plant growth and development. On a global basis, approximately one-third of lands are located in semi-

arid and arid regions, which receive only 13 to $76 \mathrm{~cm}$ of precipitation annually, and the remaining two-thirds of lands are occasionally exposed to drought conditions (Bhattacharjee and Saha, 2014). Plants under drought stress tend to reduce leaf size, stimulate leaf abscission, enhance root growth, and limit photosynthesis (Taiz et al., 2015). Some plants can maintain water balance under drought conditions through osmotic adjustment (Farooq et al., 2008). The fact that drought resistance varies among plant species warrants further investigation to evaluate plant responses to drought conditions and select drought-tolerant plants for landscape use.

Soil salinity is also a global issue and is caused partially by human activities such as irrigation with poor quality water and poor soil drainage, which result in excess soluble salts in the soil. It is estimated that $20 \%$ of the irrigated lands in the world are currently affected by salinity stress (Taiz et al., 2015). Salinity induces a series of metabolic dysfunctions in plants, including specific ion toxicity, nutrient imbalance, decreased photosynthesis, and enzyme dysfunction (Munns and Tester, 2008). The extent of adverse impact of salinity on plant physiological processes depends on the rate and duration of salinity stress. Salinity stress can damage various physiological and chemical processes and even kill the plant. Salt-tolerant plants can withstand the adverse effects of high salinity without severe foliar salt damage and significant reductions in growth and yield (Grieve et al., 2008). The ability to tolerate salinity stress varies among plant species and genotypes. Evaluating plant species commonly used in landscape for salt tolerance may aid in identifying salt-tolerant plants for landscape use.

Tatarian dogwood (Cornus alba) is a member of dogwood family (Cornaceae) that is native to Siberia, northern China, and Korea (Zhang et al., 2013). It has been introduced to North America and Europe because of its high cold hardiness and resistance to air pollution (Konarska, 2011). Tatarian dogwood is a popular ornamental shrub with white fruits, creamy-white flowers, and red stems in fall through late winter (Dirr, 2009). It is widely used in residential landscape, public parks, and botanical gardens.

The morphological and physiological responses to abiotic stress vary with species in dogwood family (Hinckley et al., 1980; Renault, 2005). Red-osier dogwood (Cornus stolonifera) has been reported to be moderately resistant to salt stress in a number of investigations (Davis et al., 2014; Mustard and Renault, 2004; Renault and Affifi, 2009). In a greenhouse study, the changes in the cell wall composition and elasticity of red-osier dogwood (Cornus sericea) under drought stress were attributed to the delay in breaking bud (Mustard and Renault, 2006). Dale et al. (2003) found that water deficit enhanced the freeze-tolerance of red-osier dogwood. Flowering dogwood (Cornus florida) has been reported to grow well in moderately compacted soil (Day et al., 2000).

However, little is known regarding the tolerance of salt and drought stresses of tatarian dogwood. Therefore, the purpose of this study was to characterize the survival, 
morphological, aesthetic, and physiological responses of tatarian dogwood seedlings to salinity and drought stresses.

\section{Materials and Methods}

\section{Plant materials}

Tatarian dogwood seeds (F.W. Schumacher Co., Sandwich, MA) in wet sands were stratified at $4{ }^{\circ} \mathrm{C}$ for 2 months starting from Dec. 2015. In February, 2016, seedlings were transplanted into $10-\mathrm{cm}$ pots with a soilless growing substrate $(45 \%$ to $55 \%$ canadian sphagnum peatmoss, vermiculite, composted bark, dolomite limestone, $0.0001 \%$ silicon dioxide $\left(\mathrm{SiO}_{2}\right)$ (Metro-Mix $360 \mathrm{RSI}$; SunGro Horticulture, Agawam, MA). These seedlings were used for both salinity and drought studies.

\section{Salinity study (Expt. 1)}

Growing substrates. Three soilless growing substrates (Metro-Mix 360, Metro-Mix 560, Metro-Mix 902; SunGro Horticulture, Agawam, MA) were used in this study. Metro-Mix 360 contains finer particles and less composted bark; it is recommended for production in relatively small containers such as propagation and transplants (Sun Gro Horticulture, 2019). Metro-Mix 560 is recommended for production in medium- to largesized containers, and Metro-Mix 902 is recommended for nursery crops and perennials and forestry (Sun Gro Horticulture, 2019). Uniform 4-month-old dogwood seedlings were transplanted into $3.8-\mathrm{L}$ plastic containers (PC1D-4, Nursery Supplies, Orange, CA) filled with one of the substrates on 1 June 2016. All plants were grown in a greenhouse in El Paso, TX (lat. $31^{\circ} 41^{\prime} 45^{\prime \prime} \mathrm{N}$, long. $106^{\circ} 16^{\prime} 54^{\prime \prime} \mathrm{W}$, elevation $1139 \mathrm{~m}$ ) following a randomized complete block design with 10 replications per treatment per substrate.

Salinity treatments. Salinity treatments were initiated on 14 June 2016 by irrigating plants with either a nutrient or a saline solution. The nutrient solution was prepared by adding $1 \mathrm{~g} \cdot \mathrm{L}^{-1} 15 \mathrm{~N}-2.2 \mathrm{P}-12.5 \mathrm{~K}$ (Peters Excel

Received for publication 5 Aug. 2019. Accepted for publication 18 Sept. 2019.

Published online 10 January 2020.

This research was supported in part by the U.S. Department of Agriculture (USDA) National Institute of Food and Agriculture Hatch project TEX090450. The authors appreciate the financial support from China Scholarship Council to Qiang Liu as a visiting graduate student at the Texas A\&M AgriLife Research Center at El Paso, TX, and China Postdoctoral Science Foundation (2019M650186). The content is solely the responsibility of the authors and does not necessarily represent the official views of the funding agencies. Mention of a trademark, proprietary product, or vendor does not constitute a guarantee or warranty of the product by the USDA or Texas A\&M University and does not imply its approval to the exclusion of other products or vendors that also may be suitable.

Y.S. and G.N. are the corresponding authors. E-mail: youping.sun@usu.edu or gniu@ag.tamu.edu.

This is an open access article distributed under the CC BY-NC-ND license (https://creativecommons.org/ licenses/by-nc-nd/4.0/).
15-5-15 Ca-Mag Special; ICL Specialty Fertilizers, Dublin, $\mathrm{OH}$ ) to reverse osmosis (RO) water, and the resulting EC was $1.2 \mathrm{dS} \cdot \mathrm{m}^{-1}$. The saline solution at an EC of $5.0 \mathrm{dS} \cdot \mathrm{m}^{-1}$ was prepared by adding $1.20 \mathrm{~g} \cdot \mathrm{L}^{-1}$ sodium chloride $(\mathrm{NaCl})$ and $1.16 \mathrm{~g} \cdot \mathrm{L}^{-1}$ calcium chloride $\left(\mathrm{CaCl}_{2}\right)$ to the nutrient solution, and the saline solution at an EC of $10.0 \mathrm{dS} \cdot \mathrm{m}^{-1}$ was prepared by adding $2.84 \mathrm{~g} \cdot \mathrm{L}^{-1} \mathrm{NaCl}$ and $2.70 \mathrm{~g} \cdot \mathrm{L}^{-1}$ $\mathrm{CaCl}_{2}$ to the nutrient solution. The $\mathrm{pH}$ of all solutions was adjusted to 6.6 using potassium hydroxide $(\mathrm{KOH})$. Both nutrient and saline solutions were prepared in 100-L tanks with EC confirmed using an EC meter (LAQUA Twin; Horiba, Ltd., Kyoto, Japan) before irrigation. From 14 June to 17 Aug. 2016, treatment solutions were applied manually roughly once per week for 8 weeks. A total of $1.0 \mathrm{~L}$ treatment solution was applied to each plant each time, resulting in a leaching fraction of $\approx 35 \%$. Between treatment solution irrigations, plants were irrigated with $500 \mathrm{~mL}$ of nutrient solution whenever the substrate surface became dry. Irrigation frequency varied with environmental condition and treatment.

Growing conditions. The temperature in the greenhouse was measured using $\mathrm{T}$ thermocouples (T-type; Omega Engineering, Stamford, CT) connected to a datalogger (CR1000; Campbell Scientific, Logan, UT). During the experiment, day and night temperature was $25.0 \pm$ $4.2{ }^{\circ} \mathrm{C}($ mean $\pm \mathrm{SD})$ and $17.2 \pm 4.2^{\circ} \mathrm{C}$, respectively. Photosynthetic photon flux was measured with a quantum sensor (Apogee Instruments, Logan, UT). Daily light integral inside the greenhouse was $9.5 \pm 4.2 \mathrm{~mol} \cdot \mathrm{m}^{-2} \cdot \mathrm{d}^{-1}$. The average relative humidity was $34.7 \% \pm 13.0 \%$.

Leachate EC. The leachate EC was determined following the pour-through methods according to Cavins et al. (2008). One plant per treatment per substrate was chosen for measurement after treatment solutions were applied. The substrate final $\mathrm{EC}_{\mathrm{e}}$ was determined using a saturated soil paste technique (Gavlak et al., 1994).

Plant growth. Plant height (centimeters) was recorded from the pot rim to the top growth point at the beginning of the experiment and on 20 July ( $36 \mathrm{~d}$ after the initiation of treatment, first harvest) and on $17 \mathrm{Aug}$. 2016 (64 d after the initiation of treatment, second harvest). At both harvest times, aboveground parts of five plants were harvested, and shoot DW was determined after oven-drying at $70{ }^{\circ} \mathrm{C}$ for $5 \mathrm{~d}$. Leaf area (square centimeters) of all living plants was determined using an area meter (LI-3100C; LI-COR Biosciences, Lincoln, NE).

Foliar salt damage evaluation. Foliar salt damage was rated by giving a visual score based on a reference scale from 0 to 5 at the end of the experiment, where $0=$ dead; $1=$ severe foliar damage $(>90 \%$ leaves with burn and necrosis at the margin); $2=$ moderate foliar damage $(90 \%$ to $50 \%) ; 3=$ slight foliar damage ( $50 \%$ to $10 \%) ; 4=$ good quality with minimal foliar damage $(<10 \%)$; and $5=$ excellent without foliar damage (Sun et al., 2015).

Gas exchange, relative chlorophyll content, and chlorophyll fluorescence. Leaf net $\mathrm{P}_{\mathrm{n}}, g_{\mathrm{S}}$, and $\mathrm{E}$ of plants were measured using a portable photosynthesis system with an automatic universal PLC6 broad leaf cuvette (CIRAS-2; PP Systems, Amesbury, MA) $1 \mathrm{~d}$ before the first and second harvest. Relative chlorophyll content (SPAD reading) was also measured using a handheld chlorophyll meter (measured as the optical density; Minolta Camera Co., Osaka, Japan). Meanwhile, to examine the effect of elevated salinity on leaf photosynthetic apparatus, minimal fluorescence $\left(\mathrm{F}_{0}\right)$, maximum fluorescence $\left(F_{m}\right)$, the maximal photochemical efficiency of PSII $\left(F_{\mathrm{v}} / \mathrm{F}_{\mathrm{m}}, \mathrm{F}_{\mathrm{v}}=\mathrm{F}_{\mathrm{m}}-\mathrm{F}_{0}\right)$, were measured using a chlorophyll fluorescence system (Pocket PEA; Hansatech, Norfolk, UK).

Mineral analysis. Leaves at the first harvest were separated from the stem to analyze $\mathrm{Na}^{+}, \mathrm{Cl}^{-}$, calcium $\left(\mathrm{Ca}^{2+}\right)$, potassium $\left(\mathrm{K}^{+}\right)$, phosphorus $(\mathrm{P})$, zinc $\left(\mathrm{Zn}^{2+}\right)$, iron $\left(\mathrm{Fe}^{3+}\right)$, sulfur (S), copper $\left(\mathrm{Cu}^{2+}\right)$, magnesium $\left(\mathrm{Mg}^{2+}\right)$, and boron (B) concentrations. Leaves were ground to pass a 40-mesh screen with a stainless Wiley mill (Thomas Scientific, Swedesboro, NJ). The powder samples were extracted using 2\% acetic acid (Fisher Scientific, Fair Lawn, NJ), and the $\mathrm{Cl}^{-}$concentration of the solution was determined using a chloride analyzer (M926; Cole Parmer Instrument Company, Vernon Hills, IL) (Gavlak et al., 1994). Powder samples were submitted to the Soil, Water and Forage Testing Laboratory at Texas A\&M University (College Station, TX) for analyzing $\mathrm{Na}^{+}$, $\mathrm{Ca}^{2+}, \mathrm{K}^{+}, \mathrm{P}, \mathrm{Zn}^{2+}, \mathrm{Fe}^{3+}, \mathrm{S}, \mathrm{Cu}^{2+}, \mathrm{Mg}^{2+}$, and $\mathrm{B}$ concentrations using an inductively coupled plasma-optical emission spectrometry (SPECTRO Analytical Instruments, Mahwah, NJ) and reported on a dry plant biomass basis (Havlin and Soltanpour,1989; Isaac and Johnson, 1975).

Experimental design and statistical analysis. The experiment used a split-plot design with the salinity treatment as the main plot and the three soilless growing substrates as the subplot with 10 replications per treatment per substrate. A two-way analysis of variance (ANOVA) was used to test the effects of soil salinity and substrates on plant growth. Means separation among treatments was conducted using Tukey's honestly significant difference multiple comparison. All statistical analyses were performed using a generalized linear model in JMP software (Version 12, SAS Institute, Cary, NC).

\section{Drought study (Expt. 2)}

Irrigation treatments. Uniform 4-monthold seedlings were transplanted into 7.6-L, injection-molded, polypropylene containers (No. 2B; Nursery Supplies, Orange, CA) filled with Metro-Mix 360 RSI on 20 June 2016. The substrate was incorporated with 25 g $15 \mathrm{~N}-3.96 \mathrm{P}-10 \mathrm{~K}$ controlled release fertilizer (Scotts Osmocote Plus 15-9-12 with 5 to 6 months' longevity; The Scotts Company, Marysville, $\mathrm{OH}$ ).

From 30 June to 1 Sept. 2016, plants were irrigated using a sensor-based automated irrigation system similar to that described by Nemali and van Iersel (2006) at one of the seven substrate VWC set points. One 
capacitance sensor (10 HS, Decagon, Pullman, WA) was inserted perpendicularly into the substrate in a randomly selected container in each treatment. The sensors were connected to a datalogger (CR10; Campbell Scientific) through a multiplexer (AM416; Campbell Scientific), and the substrate moisture was measured every 5 min. A substratespecific calibration equation converted voltage readings from the soil moisture sensors to VWC $\left(\mathrm{L} \cdot \mathrm{L}^{-1}\right)(\mathrm{VWC}=-20.99+25.349 \times$ voltage $+46.55 \times$ voltage $\left.^{2}, R^{2}=0.984\right)$. The datalogger compared the VWC in each treatment with the VWC set point for that particular treatment. As soon as the VWC in a container dropped below the set point for irrigation, the datalogger sent a signal to the 16-channel relay controller (SDM-CD16AC; Campbell Scientific), which opened the solenoid valve (X-13551-72; Dayton Electric Co., Niles, IL) corresponding to that treatment for 40 s. Each container was watered with one dribble ring (Dramm, Manitowoc, WI) at a diameter of $15 \mathrm{~cm}$ with five emitter holes per ring. The dribble ring was connected to pressure-compensated drip emitter $(8 \mathrm{LPH}$; Netafim USA, Fresno, CA) with an average flow rate of $133.3 \mathrm{~mL} \cdot \mathrm{min}^{-1}$. Seven irrigation thresholds were VWC values of $0.15 \mathrm{~L} \cdot \mathrm{L}^{-1}$ (15\%), $0.20 \mathrm{~L} \cdot \mathrm{L}^{-1}(20 \%), 0.25 \mathrm{~L} \cdot \mathrm{L}^{-1}(25 \%)$, $0.30 \mathrm{~L} \cdot \mathrm{L}^{-1}(30 \%), 0.35 \mathrm{~L} \cdot \mathrm{L}^{-1}(35 \%), 0.40$ $\mathrm{L} \cdot \mathrm{L}^{-1}(40 \%)$, and $0.45 \mathrm{~L} \cdot \mathrm{L}^{-1}(45 \%)$. Plants were watered with RO water throughout the experiment.

For drought experiment, plant height, leaf area, shoot DW, visual score, SPAD reading, gas exchange, and $\mathrm{F}_{\mathrm{v}} / \mathrm{F}_{\mathrm{m}}$ were determined as described in the salt experiment at the end of the experiment. In addition, midday leaf water potential was taken using a water potential system (Psypro; Wescor, Logan, UT). The average air temperature in the greenhouse was $26.5 \pm 3.4{ }^{\circ} \mathrm{C}$ (mean $\pm \mathrm{SD}$ ) during the day and $17.6 \pm 2.9^{\circ} \mathrm{C}$ at night. The average daily light integral was $9.7 \pm 1.3$ $\mathrm{mol} \cdot \mathrm{m}^{-2} \cdot \mathrm{d}^{-1}$ and the average relative humidity was $36.2 \% \pm 11.8 \%$ during the experiment period. During the experiment, Abamectin (AVID 0.15 EC; Syngenta Crop Protection, Greensboro, NC) at $0.1 \mathrm{~mL}$ per gallon was sprayed three times to control thrips (Thysanoptera) and/or aphids (Aphidoidea).

Experimental design and statistical analysis. All plants were arranged in the greenhouse following a randomized complete block design with seven treatments (VWC thresholds), two blocks, and four plants per treatment in each block. All data were subjected to ANOVA analysis. Means separation among treatments was conducted using Tukey's honest significant difference multiple comparison. All statistical analyses were performed using a generalized linear model in JMP software (Version 12, SAS Institute, Cary, NC).

\section{Results and Discussion}

\section{Salinity study (Expt. 1)}

Substrates did not affect the EC values of leachate solutions; therefore, data were pooled across substrate. The average EC of leachate solutions ranged from 2.5 to 4.5 $\mathrm{dS} \cdot \mathrm{m}^{-1}$ for the control (Fig. 1). When saline solutions at an EC of 5.0 or $10.0 \mathrm{dS} \cdot \mathrm{m}^{-1}$ were applied, the average EC of the leachate solutions was from 5.6 to $10.7 \mathrm{dS} \cdot \mathrm{m}^{-1}$ and from 8.1 to $15.1 \mathrm{dS} \cdot \mathrm{m}^{-1}$, respectively (Fig. 1). These results indicated that salts accumulated in the root zone. At the second harvest ( $66 \mathrm{~d}$ after the initiation of treatment), the substrate ECe was $1.9 \pm 0.5,3.7 \pm 0.9$, and $5.0 \pm 1.3 \mathrm{dS} \cdot \mathrm{m}^{-1}$, respectively, for the irrigation with nutrient solutions (control) and saline solutions at an $\mathrm{EC}$ of 5.0 or $10.0 \mathrm{dS} \cdot \mathrm{m}^{-1}$ (data not shown).

There was no significant difference in growth and physiological parameters among substrate types and no interaction between substrate and salinity was found in this study (Tables 1 and 2). All data were pooled across substrates. When irrigated with saline solusalt damage was observed on tatarian dogwood plants with an average visual score of 2.4 at 3 weeks after the initiation of treatments, and all plants died at 5 weeks after the initiation of treatments (data not shown). At both harvests, plants irrigated with saline solutions at an EC of $5.0 \mathrm{dS} \cdot \mathrm{m}^{-1}$ exhibited slight and severe foliar salt damage with an average visual score of 3.4 and 1.0, respectively (Table 1). A significant reduction of $34.9 \%$ in leaf area was observed in tatarian dogwood plants irrigated with saline solutions at an EC of $5.0 \mathrm{dS} \cdot \mathrm{m}^{-1}$ at the first harvest (Table 1). In addition, tatarian dogwood plants irrigated with saline solutions at an EC of $5.0 \mathrm{dS} \cdot \mathrm{m}^{-1}$ had $89.1 \%$ less leaf area than those in the control at the second harvest. Severe foliar damage and small leaf area induced by salinity stress has been widely reported in glycophyte plants (Abdullah et al., 2001). tions at an EC of $10.0 \mathrm{dS} \cdot \mathrm{m}^{-1}$, severe foliar

Plants irrigated with saline solutions at an EC of $5.0 \mathrm{dS} \cdot \mathrm{m}^{-1}$ were $36.7 \%$ shorter and had $20.9 \%$ less shoot DW than those in the control at the first harvest, and more reductions of height $(50.9 \%)$ and shoot DW $(55.0 \%)$ were observed at the second harvest (Table 1). When irrigated with saline solutions at an EC of $10.0 \mathrm{dS} \cdot \mathrm{m}^{-1}$, plants were $65.1 \%$ shorter and accumulated $45.2 \%$ less shoot DW compared with the control at the first harvest. Generally, woody ornamental plants are considered sensitive to salinity stress with growth reductions greater than $50 \%$ when subjected to soil salinity levels of 4.8 or $7.8 \mathrm{dS} \cdot \mathrm{m}^{-1}$ for a 6 -month period (Cassaniti et al., 2012). In this study, more than $50 \%$ growth reductions were observed under saline solution irrigation for only 2 months. Tatarian dogwood might be considered a salt-sensitive species. Red-osier dogwood (Cornus stolonifera) were also sensitive to salt stress, and the seedlings treated with $50 \mathrm{mmol} \cdot \mathrm{L}^{-1} \mathrm{NaCl}$ for $30 \mathrm{~d}$ became $16 \%$ shorter and accumulated 39\% less shoot dry mass than the control (Mustard and Renault, 2006).

Compared with the control, significant reductions in SPAD reading and $\mathrm{P}_{\mathrm{n}}$ were observed for those plants irrigated with saline solutions at an EC of 5.0 and $10.0 \mathrm{dS} \cdot \mathrm{m}^{-1}$ at both harvests (Table 2). Leaf discoloration induced by salinity stress has been reported to associate with reductions in SPAD readings and $P_{n}$ (Niu et al., 2007). In addition, saline solutions at an EC of $5.0 \mathrm{dS} \cdot \mathrm{m}^{-1}$ did not affect the $g_{\mathrm{S}}$ and $\mathrm{E}$ of tatarian dogwood plants at both harvests. However, saline solutions at an $\mathrm{EC}$ of $10.0 \mathrm{dS} \cdot \mathrm{m}^{-1}$ reduced the $g_{\mathrm{S}}$ and $\mathrm{E}$ of tatarian dogwood plants. This is similar to previous studies on other species (Khayyat et al., 2016; Sun et al., 2018).

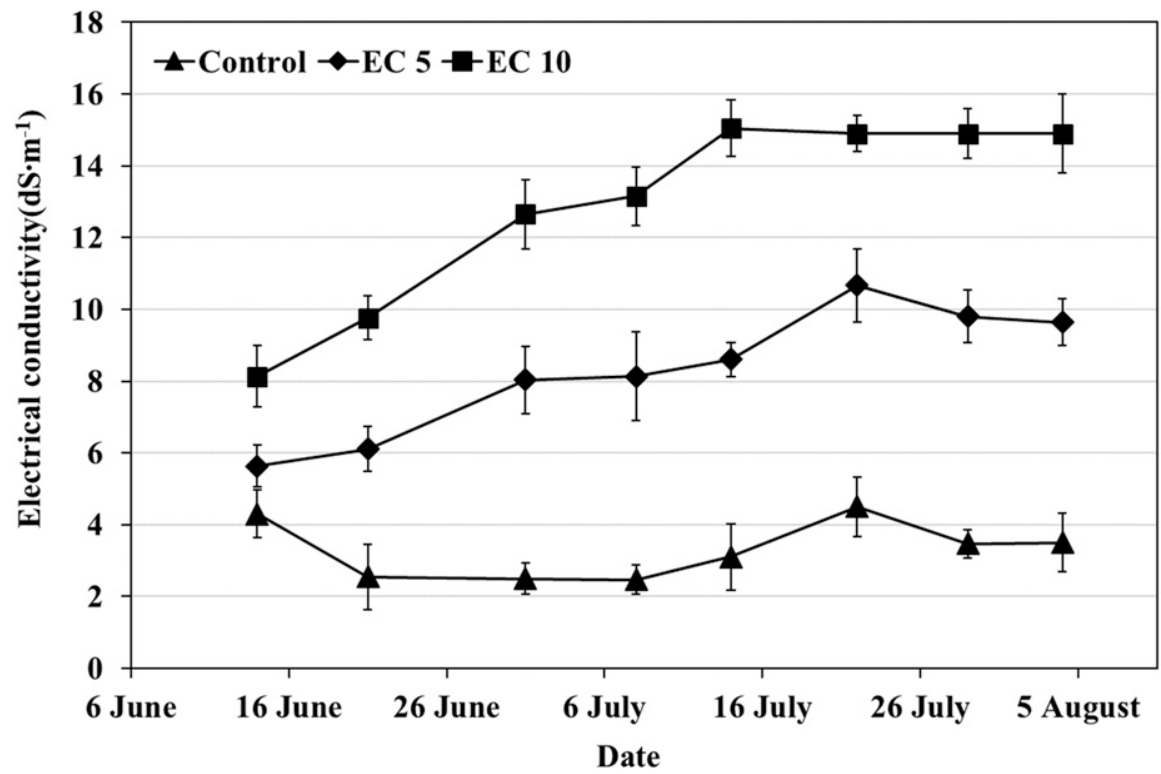

Fig. 1. Time course of the weekly leachate electrical conductivity (EC) during the experimental period. Control represents a nutrient solution at an EC of $1.2 \mathrm{dS} \cdot \mathrm{m}^{-1}$; EC 5 represents a saline solution at an EC of $5.0 \mathrm{dS} \cdot \mathrm{m}^{-1}$; and EC 10 represents a saline solution at an EC of $10.0 \mathrm{dS} \cdot \mathrm{m}^{-1}$. Substrates did not affect leachate EC; therefore, data were pooled across substrate. Vertical bars represent the SD of nine measurements, three per substrate. 
Chlorophyll fluorescence is usually measured to reflect photochemical damage to plants under salinity stress as indicate by decreases in $\mathrm{F}_{\mathrm{v}} / \mathrm{F}_{\mathrm{m}}$ (Thomas and Turner, 2001). At the first harvest, plants irrigated with saline solutions at an EC of $10.0 \mathrm{dS} \cdot \mathrm{m}^{-1}$ decreased the $F_{v} / F_{m}$ values compared with the control, but this was not the case for those plants irrigated with saline solutions at an EC of $5.0 \mathrm{dS} \cdot \mathrm{m}^{-1}$ (Table 2). At the second harvest, plants irrigated with saline solutions at an EC of $5.0 \mathrm{dS} \cdot \mathrm{m}^{-1}$ also had reduced $\mathrm{F}_{\mathrm{v}} / \mathrm{F}_{\mathrm{m}}$ values compared with the control. Many studies have revealed that the response of chlorophyll fluorescence to salinity stress varied with plant species, the salinity levels and duration. For example, saline irrigation water at an EC of 5.0 and $10.0 \mathrm{dS} \cdot \mathrm{m}^{-1}$ did not influence the $\mathrm{F}_{\mathrm{v}} / \mathrm{F}_{\mathrm{m}}$ values of the saltsensitive species in Lamiaceae, such as Ajuga reptans (bugleweed), Poliomintha longiflora (Mexican oregano), and Scutellaria suffrutescens (cherry skullcap) (Wu et al., 2016). However, Niu et al. (2008) found that the $\mathrm{F}_{\mathrm{v}} / \mathrm{F}_{\mathrm{m}}$ values decreased quadratically as the salinity levels of irrigation water increased. Liu et al. (2017) reported that saline solution at an EC of $5.0 \mathrm{dS} \cdot \mathrm{m}^{-1}$ did not influence the $\mathrm{F}_{\mathrm{v}} / \mathrm{F}_{\mathrm{m}}$ values of Diervilla rivularis (mountain bush-honeysuckle) plants at 5 weeks after the initiation of treatment but significantly reduced the $\mathrm{F}_{\mathrm{v}} / \mathrm{F}_{\mathrm{m}}$ values of Diervilla rivularis plants at 9 weeks after the initiation of treatment. Therefore, it would be difficult to assess the salt tolerance solely relying on chlorophyll fluorescence (Cai et al., 2014a).

Saline solutions at an EC of 5.0 and 10.0 $\mathrm{dS} \cdot \mathrm{m}^{-1}$ significantly increased the leaf $\mathrm{Na}^{+}$ and $\mathrm{Cl}^{-}$concentrations of tatarian dogwood plants (Table 3). Leaf $\mathrm{Na}^{+}$concentration of tatarian dogwood plants irrigated with saline solutions at an EC of 5.0 and $10.0 \mathrm{dS} \cdot \mathrm{m}^{-1}$ was 11 and 40 times more than that in the control, respectively. The leaf $\mathrm{Cl}^{-}$concentrations of tatarian dogwood plants irrigated with saline solutions at an EC of 5.0 and $10.0 \mathrm{dS} \cdot \mathrm{m}^{-1}$ was 25 and 33 times greater than that in the control, respectively. In addition, leaf $\mathrm{Ca}^{2+}$ concentration of tatarian dogwood plants was significantly increased by $38.5 \%$ and $28.6 \%$ when irrigated with saline solutions at an EC of 5.0 and $10.0 \mathrm{dS} \cdot \mathrm{m}^{-1}$, respectively. However, the $\mathrm{K}^{+}$concentration in tatarian dogwood plants irrigated with saline solutions at an EC of 5.0 and $10.0 \mathrm{dS} \cdot \mathrm{m}^{-1}$ was 1.3 to 1.5 times as that in the control. These results are similar to previous work done on the salt sensitive ornamental species such as Chaenomeles speciose (flowering quince) and Diervilla rivularis that exhibit severe foliar salt damage with reduced plant growth and photosynthesis and have relatively high $\mathrm{Na}^{+}$ and $\mathrm{Cl}^{-}$concentrations in the leaf (Liu et al., 2017). Reduction in the growth and photosynthesis of Asteriscus maritimus (gold coin daisy) clearly is associated with a large amount of $\mathrm{Na}^{+}$and $\mathrm{Cl}^{-}$in the leaves (Rodríguez et al., 2005). High $\mathrm{Na}^{+}$or $\mathrm{Cl}^{-}$ concentrations (or both) accumulated in leaf tissue may damage the chloroplasts and thus inhibit photosynthesis (Taiz et al., 2015).

Table 1. Visual score, plant height, shoot dry weight, and leaf area of Cornus alba seedlings irrigated with a nutrient solution [electrical conductivity $(\mathrm{EC})=1.2 \mathrm{dS} \cdot \mathrm{m}^{-1}$; control] or saline solution $[\mathrm{EC}=5.0$ $\mathrm{dS} \cdot \mathrm{m}^{-1}$ (EC 5) or $10.0 \mathrm{dS} \cdot \mathrm{m}^{-1}$ (EC 10)] in a greenhouse. Data were pooled across substrate type because the effects of substrate type on plant growth were not significant. Plants were harvested after the fifth (first harvest, $36 \mathrm{~d}$ after the initiation of treatment) and eighth irrigation (second harvest, $64 \mathrm{~d}$ after the initiation of treatment).

\begin{tabular}{|c|c|c|c|c|c|c|}
\hline & \multicolumn{3}{|c|}{ First harvest } & \multicolumn{3}{|c|}{ Second harvest } \\
\hline & Control & EC 5 & $\overline{\mathrm{EC} 10}$ & Control & EC 5 & EC 10 \\
\hline Visual score & $4.8 \mathrm{a}^{\mathrm{z}}$ & $3.4 \mathrm{~b}$ & $0.2 \mathrm{c}$ & $4.8 \mathrm{a}$ & $1.0 \mathrm{~b}$ & $0 \mathrm{c}$ \\
\hline Leaf area $\left(\mathrm{cm}^{2}\right)$ & $1895.1 \mathrm{a}$ & $1233.2 \mathrm{~b}$ & $-\mathrm{y}$ & $3621.6 \mathrm{a}$ & $393.0 \mathrm{~b}$ & $-\mathrm{x}$ \\
\hline Height $(\mathrm{cm})$ & $26.5 \mathrm{a}$ & $16.8 \mathrm{~b}$ & $9.3 \mathrm{c}$ & $35.8 \mathrm{a}$ & $17.6 \mathrm{~b}$ & $-\mathrm{x}$ \\
\hline Shoot dry weight (g) & $16.0 \mathrm{a}$ & $12.6 \mathrm{~b}$ & $8.7 \mathrm{c}$ & $29.9 \mathrm{a}$ & $13.4 \mathrm{~b}$ & $-^{x}$ \\
\hline
\end{tabular}

${ }^{\mathrm{z}}$ Means with same lowercase letters within harvest and parameters are not significantly different among treatments by Tukey's honestly significant difference multiple comparison or between treatments by Student's $t$ test at $P<0.05$.

${ }^{\mathrm{y}}$ Data were not collected because survived plants had severe foliar salt damage.

${ }^{\mathrm{x}}$ All plants were dead.

Table 2. Plant relative chlorophyll content [soil plant analysis development (SPAD)], chlorophyl fluorescence $\left(\mathrm{F}_{\mathrm{v}} / \mathrm{F}_{\mathrm{m}}\right)$, net photosynthesis rate $\left(\mathrm{P}_{\mathrm{n}}\right)$, stomatal conductance $\left(g_{\mathrm{S}}\right)$, and transpiration rate (E) of Cornus alba seedlings irrigated with a nutrient solution [electrical conductivity $(\mathrm{EC})=1.2$ $\mathrm{dS} \cdot \mathrm{m}^{-1}$; control] or saline solution $\left[\mathrm{EC}=5.0 \mathrm{dS} \cdot \mathrm{m}^{-1}(\mathrm{EC} 5)\right.$ or $\left.10.0 \mathrm{dS} \cdot \mathrm{m}^{-1}(\mathrm{EC} 10)\right]$ in a greenhouse. Date was taken after the fifth (first harvest, $36 \mathrm{~d}$ after the initiation of treatment) and eighth irrigation (second harvest, $64 \mathrm{~d}$ after the initiation of treatment).

\begin{tabular}{lcrrrrrr}
\hline & \multicolumn{3}{c}{ First harvest } & & \multicolumn{3}{c}{ Second harvest } \\
\cline { 2 - 4 } \cline { 6 - 8 } & Control & EC 5 & EC 10 & & Control & EC 5 & EC 10 \\
\hline SPAD & $40.4 \mathrm{a}$ & $32.2 \mathrm{~b}$ & $28.3 \mathrm{~b}$ & $36.2 \mathrm{a}$ & $30.0 \mathrm{~b}$ & $-{ }^{\mathrm{z}}$ \\
$\mathrm{P}_{\mathrm{n}}\left(\mu \mathrm{mol} \cdot \mathrm{m}^{-2} \cdot \mathrm{s}^{-1}\right)$ & $7.7 \mathrm{a}$ & $6.1 \mathrm{~b}$ & $3.9 \mathrm{~b}$ & $5.3 \mathrm{a}$ & $1.1 \mathrm{~b}$ & - \\
$g_{\mathrm{S}}\left(\mathrm{mmol} \cdot \mathrm{m}^{-2} \cdot \mathrm{s}^{-1}\right)$ & $218.5 \mathrm{a}$ & $178.9 \mathrm{ab}$ & $107.8 \mathrm{~b}$ & $123.0 \mathrm{a}$ & $107.3 \mathrm{a}$ & - \\
$\mathrm{E}\left(\mathrm{mmol} \cdot \mathrm{m}^{-2} \cdot \mathrm{s}^{-1}\right)$ & $3.6 \mathrm{a}$ & $3.1 \mathrm{ab}$ & $2.4 \mathrm{~b}$ & $2.6 \mathrm{a}$ & $2.2 \mathrm{a}$ & - \\
$\mathrm{F}_{\mathrm{v}} / \mathrm{F}_{\mathrm{m}}$ & $0.8 \mathrm{a}^{\mathrm{y}}$ & $0.8 \mathrm{a}$ & $0.7 \mathrm{~b}$ & $0.8 \mathrm{a}$ & $0.7 \mathrm{~b}$ & - \\
\hline
\end{tabular}

${ }^{\mathrm{z}}$ All plants were dead.

${ }^{\mathrm{y}}$ Means with same lowercase letters within harvest and parameters are not significantly different among treatments by Tukey's honestly significant difference multiple comparison or between treatments by Student's $t$ test at $P<0.05$.

Table 3. Leaf mineral concentrations of Cornus alba seedlings irrigated with a nutrient solution at an electrical conductivity (EC) of $1.2 \mathrm{dS} \cdot \mathrm{m}^{-1}$ (control) or saline solution at an EC of $5.0 \mathrm{dS} \cdot \mathrm{m}^{-1}$ (EC 5) or $10.0 \mathrm{dS} \cdot \mathrm{m}^{-1}$ (EC 10) in a greenhouse. Plant leaf samples at the first harvest ( $36 \mathrm{~d}$ after the initiation of treatment) were used for the analyses.

\begin{tabular}{|c|c|c|c|c|c|c|c|c|c|c|c|}
\hline \multirow[b]{2}{*}{ Treatment } & \multicolumn{11}{|c|}{ Mineral concn (mg. $\mathrm{g}^{-1}$ dry biomass) } \\
\hline & $\mathrm{Na}^{+}$ & $\mathrm{Cl}^{-}$ & $\mathrm{Ca}^{2+}$ & $\mathrm{K}^{+}$ & $\mathrm{P}$ & $\mathrm{Zn}^{2+}$ & $\mathrm{Fe}^{3+}$ & $\mathrm{S}$ & $\mathrm{Cu}^{2+}$ & $\mathrm{Mg}^{2+}$ & B \\
\hline Control & $0.13 \mathrm{c}^{\mathrm{z}}$ & $1.9 \mathrm{c}$ & $23.24 \mathrm{~b}$ & $21.32 \mathrm{c}$ & $3.93 \mathrm{a}$ & $0.035 \mathrm{a}$ & $0.152 \mathrm{a}$ & $3.57 \mathrm{a}$ & $0.0029 \mathrm{~b}$ & $6.37 \mathrm{a}$ & $0.079 \mathrm{ab}$ \\
\hline EC 5 & $1.56 \mathrm{~b}$ & $49.3 \mathrm{~b}$ & $32.18 \mathrm{a}$ & $26.69 \mathrm{~b}$ & $3.77 \mathrm{a}$ & $0.027 \mathrm{~b}$ & $0.078 \mathrm{~b}$ & $2.89 \mathrm{~b}$ & $0.0029 \mathrm{~b}$ & $7.62 \mathrm{a}$ & $0.090 \mathrm{a}$ \\
\hline EC 10 & $5.29 \mathrm{a}$ & $65.0 \mathrm{a}$ & $29.88 \mathrm{a}$ & $31.55 \mathrm{a}$ & $2.95 \mathrm{~b}$ & $0.026 \mathrm{~b}$ & $0.063 \mathrm{~b}$ & $2.58 \mathrm{~b}$ & $0.0035 \mathrm{a}$ & $7.42 \mathrm{a}$ & $0.069 \mathrm{~b}$ \\
\hline
\end{tabular}

${ }^{\mathrm{z}}$ Means with same lowercase letters within column are not significantly different among treatments by Tukey's honestly significant difference multiple comparison at $P<0.05$.

Noteworthy, for salinity level at an EC of $5.0 \mathrm{dS} \cdot \mathrm{m}^{-1}$ at both harvests (Table 2), there was significant reduction in photosynthesis rate and high accumulation of $\mathrm{Na}^{+}$and $\mathrm{Cl}^{-}$in the leaves compared with control, without reductions in $g_{\mathrm{S}}$ and transpiration rate. This might indicate the maintenance of $g_{S}$ and transpiration rate could contribute to the greater accumulation of $\mathrm{Na}^{+}$and $\mathrm{Cl}^{-}$in leaves. Cai et al. (2014b) also reported that the high salinity level at an EC of $10.0 \mathrm{dS} \cdot \mathrm{m}^{-1}$ reduced $\mathrm{P}_{\mathrm{n}}$, but not $g_{\mathrm{S}}$ and $\mathrm{E}$, in rose cultivar 'Else Poulsen'. Therefore, tatarian dogwood seedlings are sensitive to the high accumulation of $\mathrm{Na}^{+}$and $\mathrm{Cl}^{-}$in the leaves, which may be a good indicator of salt sensitivity.

Mineral elements such as $\mathrm{P}, \mathrm{Zn}^{2+}, \mathrm{Fe}^{3+}$, and $\mathrm{S}$ decreased in tatarian dogwood plants under saline solution irrigation with reductions of $4.1 \%, 22.9 \%, 48.7 \%$, and $19.1 \%$ at an EC of $5.0 \mathrm{dS} \cdot \mathrm{m}^{-1}$, respectively, and $24.9 \%$,
$25.7 \%, 58.6 \%$, and $27.7 \%$ at an EC of 10 $\mathrm{dS} \cdot \mathrm{m}^{-1}$, respectively (Table 3 ). However, saline solutions at an EC of $5.0 \mathrm{dS} \cdot \mathrm{m}^{-1} \mathrm{did}$ not affect the $\mathrm{Cu}^{2+}, \mathrm{Mg}^{2+}$, and $\mathrm{B}$ concentrations of tatarian dogwood plants. Saline solutions at an EC of $10.0 \mathrm{dS} \cdot \mathrm{m}^{-1}$ increased $\mathrm{Cu}^{2+}$ concentration by $20.6 \%$ and decreased B concentration by $13.4 \%$. These results are in agreement with other studies. For example, Sharpley et al. (1992) found salinity-reduced $\mathrm{P}$ concentrations in plant tissues may result from reduced activity of $\mathrm{P}$ in the soil solution due to the high ionic strength of the media and low solubility of Ca-P minerals (Grattan and Grieve, 1999). The $\mathrm{Mg}^{2+}$ concentration in six garden roses at elevated salinity was not significant increased compared with the control (Niu et al., 2013). However, Petropoulos et al. (2017) indicated that salinity stress increased the $\mathrm{Fe}$ and $\mathrm{Zn}$ concentrations in Cichorium spinosum, a salt tolerant plant, 
which is in contrast to our study. The salinityinduced mineral nutritional disorders may occur depending on plant species.

\section{Drought study (Expt. 2)}

The daily average substrate VWC decreased and reached the corresponding set points at $19 \mathrm{~d}$ after the initiation of automatic irrigation (Fig. 2). Since then, the daily average substrate VWCs were maintained above the set points throughout the experiment. The average VWC, representing measurements from 19 to $62 \mathrm{~d}$ after automatic irrigation initiation, was $17.3 \%, 21.8 \%, 26.1 \%, 31.2 \%$,
$36.0 \%, 43.3 \%$, and $45.8 \%$ for the irrigation set points of $15 \%, 20 \%, 25 \%, 30 \%, 35 \%$, $40 \%$, and $45 \%$, respectively. The fact that the average VWC at the lowest set point was higher than that of its set point could be the result of lower substrate hydraulic conductivity when substrates have a lower VWC (Naasz et al., 2005).

Plant height, leaf area, and shoot DW of tatarian dogwood seedlings decreased linearly with decreasing VWC with the linear regression coefficients $\left(R^{2}\right)$ of $0.92,0.95$, and 0.96 , respectively (Fig. 3). When VWC decreased from $45 \%$ to $15 \%$, plant height, leaf

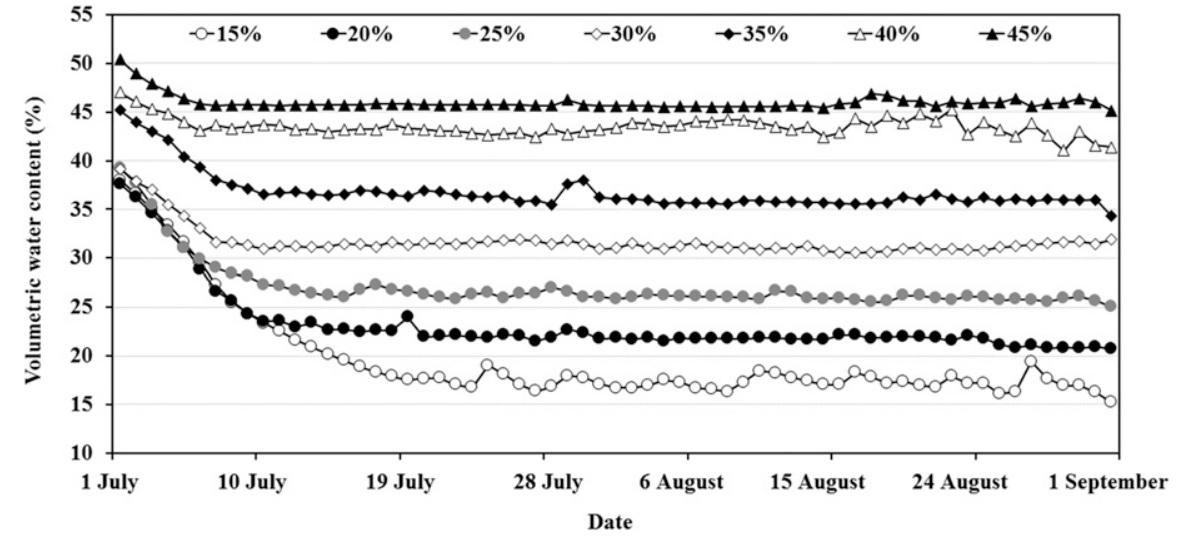

Fig. 2. Daily average substrate volumetric water contents maintained by a soil moisture sensor-controlled automatic irrigation system. Substrate volumetric water content (VWC, \%) is volume of water/volume of substrate. area, and shoot DW decreased by $66.4 \%$, $84.8 \%$, and $85.5 \%$, respectively. GarcíaCaparrós et al. (2019) reported that a significant reduction of shoot DW was observed on Lavandula latifolia (broadleaved lavender), Mentha piperita (peppermint), and Thymus capitatus (spanish oregano) under water deprivation. Govahi et al. (2015) reported that water stress resulted in a reduction of fresh weight in Salvia officinalis (common sage) plants.

Although growth was stunted by drought stress, there was no foliar damage in tatarian dogwood seedlings among the seven VWC treatments except for $15 \%$ VWC treatment, which exhibited slight foliar drought damage with an average visual score of 3.6 (Fig. 3). For agricultural crops, drought tolerance is often assessed based on the growth or yield reduction of specific plant parts such as seeds, roots, fruits, or leaves (Jones, 1993). However, for landscape plants, survival and aesthetic value are more important than growth rate (Niu and Cabrera, 2010). Therefore, tatarian dogwood seedlings survived in water-deficit condition with acceptable visual quality.

There were no significant differences in SPAD readings of tatarian dogwood seedlings among VWC treatments (Table 4). As far as gas exchange parameters were concerned, significant reductions were found in leaf net $\mathrm{P}_{\mathrm{n}}, g_{\mathrm{S}}$, or $\mathrm{E}$ of tatarian dogwood seedling plants at the VWC treatment of $15 \%$
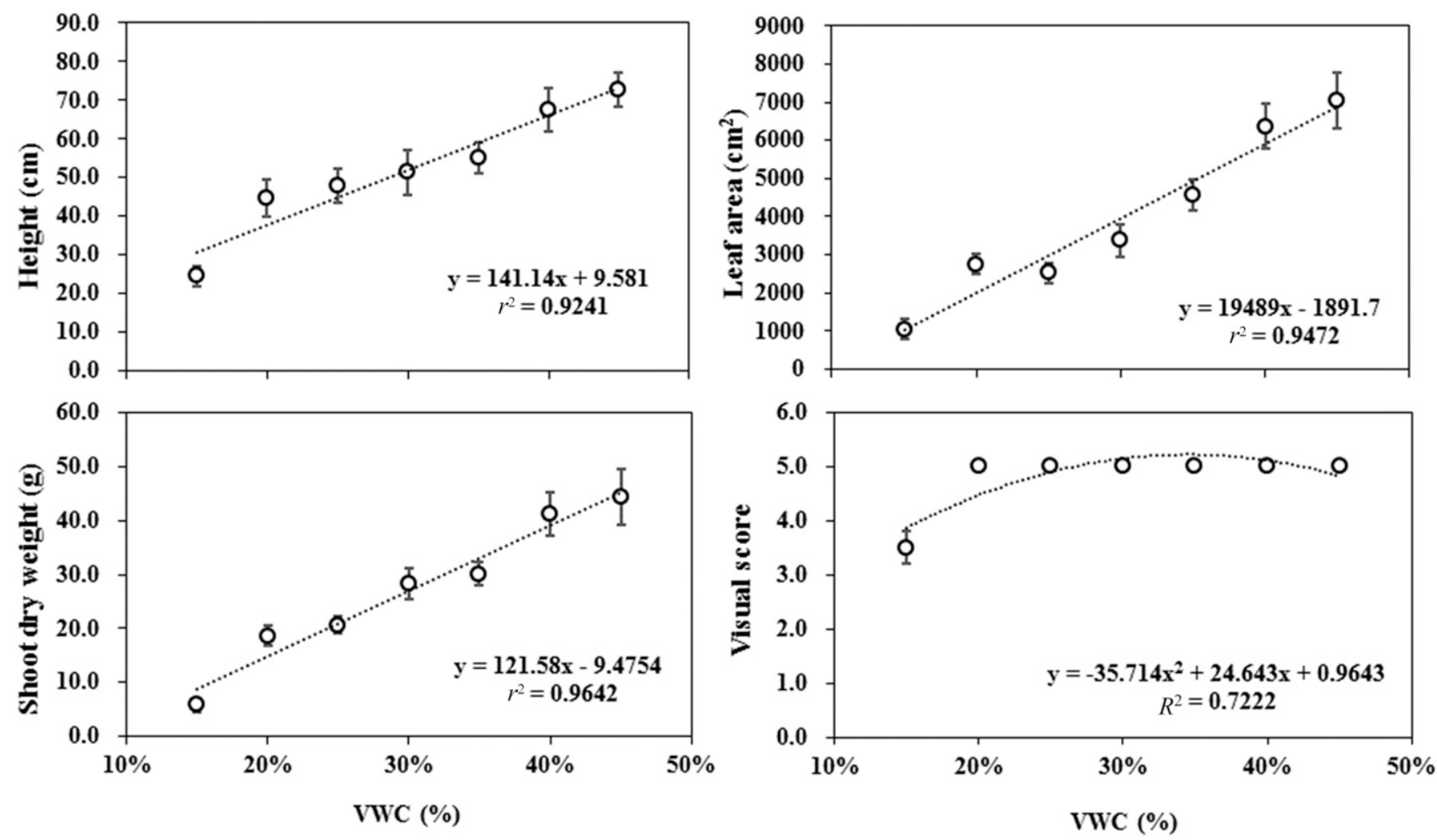

Fig. 3. Morphological responses and visual score of Cornus alba seedlings that were irrigated for $63 \mathrm{~d}$ with various substrate volumetric water contents (VWC; volume of water/volume of substrate) maintained using a soil moisture sensor-controlled automatic irrigation system. Visual score: $0=$ dead; $1=$ severe foliar damage ( $>90 \%$ leaves with burn and necrosis at the margin); $2=$ moderate foliar damage $(90 \%$ to $50 \%)$; $3=$ slight foliar damage $(50 \%$ to $10 \%) ; 4=$ good quality with minimal foliar damage $(<10 \%)$; and $5=$ excellent without foliar damage (Sun et al., 2015). 
Table 4. Relative chlorophyll content [soil plant analysis development (SPAD)], net photosynthesis rate $\left(\mathrm{P}_{\mathrm{n}}\right)$, stomatal conductance $\left(g_{\mathrm{S}}\right)$, and transpiration rate $(\mathrm{E})$, chlorophyll fluorescence $\left(\mathrm{F}_{\mathrm{v}} / \mathrm{F}_{\mathrm{m}}\right)$, and water potential (WP) of Cornus alba seedlings that were irrigated for $63 \mathrm{~d}$ with various substrate volumetric water contents (VWCs) maintained using a soil moisture sensor-controlled automatic irrigation system.

\begin{tabular}{lcccccc}
\hline VWC & SPAD & $\mathrm{P}_{\mathrm{n}}\left(\mu \mathrm{mol} \cdot \mathrm{m}^{-2} \cdot \mathrm{s}^{-1}\right)$ & $g_{\mathrm{S}}\left(\mathrm{mmol} \cdot \mathrm{m}^{-2} \cdot \mathrm{s}^{-1}\right)$ & $\mathrm{E}\left(\mathrm{mmol} \cdot \mathrm{m}^{-2} \cdot \mathrm{s}^{-1}\right)$ & $\mathrm{F}_{\mathrm{v}} / \mathrm{F}_{\mathrm{m}}$ & $\mathrm{WP}(\mathrm{MPa})$ \\
\hline $15 \%$ & $37.3 \mathrm{a}^{\mathrm{z}}$ & $5.95 \mathrm{~b}$ & $168.6 \mathrm{~b}$ & $2.35 \mathrm{~b}$ & $0.80 \mathrm{a}$ & $-2.89 \mathrm{a}$ \\
$20 \%$ & $39.0 \mathrm{a}$ & $11.49 \mathrm{a}$ & $685.3 \mathrm{ab}$ & $5.38 \mathrm{a}$ & $0.82 \mathrm{a}$ & $-2.60 \mathrm{a}$ \\
$25 \%$ & $39.0 \mathrm{a}$ & $9.61 \mathrm{ab}$ & $558.4 \mathrm{ab}$ & $5.12 \mathrm{a}$ & $0.82 \mathrm{a}$ & $-2.39 \mathrm{a}$ \\
$30 \%$ & $39.3 \mathrm{a}$ & $10.51 \mathrm{ab}$ & $671.9 \mathrm{ab}$ & $5.59 \mathrm{a}$ & $0.82 \mathrm{a}$ & $-2.02 \mathrm{a}$ \\
$35 \%$ & $36.8 \mathrm{a}$ & $8.75 \mathrm{ab}$ & $649.1 \mathrm{a}$ & $5.36 \mathrm{a}$ & $0.82 \mathrm{a}$ & $-1.79 \mathrm{a}$ \\
$40 \%$ & $37.5 \mathrm{a}$ & $10.01 \mathrm{ab}$ & $795.0 \mathrm{a}$ & $5.45 \mathrm{a}$ & $0.83 \mathrm{a}$ & $-2.05 \mathrm{a}$ \\
$45 \%$ & $35.6 \mathrm{a}$ & $10.25 \mathrm{ab}$ & $1044.7 \mathrm{a}$ & $5.76 \mathrm{a}$ & $0.83 \mathrm{a}$ & $-1.77 \mathrm{a}$ \\
Linear & $\mathrm{NS}$ & $\mathrm{NS}$ & $*$ & $\mathrm{NS}$ & NS & $*$ \\
Quadratic & $\mathrm{NS}$ & $\mathrm{NS}$ & $\mathrm{NS}$ & $\mathrm{NS}$ & $\mathrm{NS}$ & $\mathrm{NS}$ \\
\hline
\end{tabular}

${ }^{\mathrm{z}}$ Means with same lowercase letters within column are not significantly different among VWC treatments by Tukey's honestly significant difference multiple comparison at $P<0.05$.

NS, $*, * *, * * *$ Nonsignificant or significant at $P<0.05,0.01$, or 0.001 , respectively.

(Table 4). These results corresponded to the significant reductions in plant height, leaf area, and shoot DW. Zhen et al. (2014) concluded that slow growth at low VWC may be caused by the low photosynthetic activity due to drought stress. Under drought stress conditions, plants close their stomata to reduce the transpiration and the $\mathrm{CO}_{2}$ influx, resulting in a decrease in photosynthesis (Yokota et al., 2002). Drought stress also reduces leaf area, which reduces photosynthetic rate per plant, hence reducing shoot dry growth.

The $\mathrm{F}_{\mathrm{v}} / \mathrm{F}_{\mathrm{m}}$ of tatarian dogwood seedlings measured in the morning and in the afternoon was not significant among treatments in current study (Table 4), which indicated that the photosynthesis system II (PSII) was not affected. Instead of damaged PSII photochemistry, tatarian dogwood seedlings adapt to drought stress by restricting $\mathrm{CO}_{2}$ supply and water uptake to limit the photosynthesis at the VWC treatment of $15 \%$. Small or no differences in $\mathrm{F}_{\mathrm{v}} / \mathrm{F}_{\mathrm{m}}$ have been reported when plants were drought stressed (Maxwell and Johnson, 2000; Starman and Lombardini, 2006). Zhen et al. (2014) reported that Aquilegia canadensis (canadian columbine) plants gradually exposed to low rates of drought stress had reduced $\mathrm{P}_{\mathrm{n}}$ and $g_{\mathrm{S}}$, but no detectable differences on $\mathrm{F}_{\mathrm{v}} / \mathrm{F}_{\mathrm{m}}$. SánchezBlanco et al. (2009) also observed no drought-induced damage to PSII of Pelargonium zonale (zonal geranium). These results suggest that tatarian dogwood plants may possess a greater capacity to counter photosynthetic damage through alternative mechanisms when photochemistry is stomatallimited, such as increased photorespiration (Voss et al., 2013).

In this study, as VWC decreased from $45 \%$ to $15 \%$, water potential reduced linearly from -1.77 to $-2.89 \mathrm{MPa}$ (Table 4). This result might indicate that tatarian dogwood could use osmotic adjustment to maintain water relations under drought stress. Plants under water deficit can lower water potential via accumulated solutes in the cells to attract water into the cell and to maintain turgor pressure (Subbarao et al., 2000). Actually, in a similar study, tatarian dogwood plants could improve the osmotic regulation ability to maintain its cell turgor for preventing plants from water loss and wilt under water deficit (Xu et al., 2011).

In summary, salt stress significantly impacted the plant growth of tatarian dogwood seedlings. All plants died when irrigated with saline solutions at an EC of $10.0 \mathrm{dS} \cdot \mathrm{m}^{-1}$, and those plants irrigated with saline solutions at an EC of $5.0 \mathrm{dS} \cdot \mathrm{m}^{-1}$ exhibited severe foliar damage. Leaf $\mathrm{Na}^{+}$and $\mathrm{Cl}^{-}$concentrations of tatarian dogwood seedlings irrigated with saline solutions were excessively higher than those in the control. Drought stress decreased plant growth of tatarian dogwood seedlings, but all plants survived at all VWC treatments. Significant reductions in the gas exchange parameters $\left(\mathrm{P}_{\mathrm{n}}, g_{\mathrm{S}}\right.$, and $\left.\mathrm{E}\right)$ and water potential at VWC of $15 \%$ were observed, but SPAD reading and $\mathrm{F}_{\mathrm{v}} / \mathrm{F}_{\mathrm{m}}$ of tatarian dogwood plants were similar among the different VWCs, and the photosynthesis system of plants was not damaged by drought stress. On the basis of the results described here, tatarian dogwood is salt sensitive but is drought tolerant.

\section{Literature Cited}

Abdullah, Z., M.A. Khan, and T.J. Flowers. 2001. Causes of sterility in seed set of rice under salinity stress. J. Agron. Crop Sci. 187:25-32.

Bhattacharjee, S. and A.K. Saha. 2014. Plant waterstress response mechanisms, p. 149-172. In: R.K. Gaur and P. Sharma (eds.). Approaches to plant stress and their management. Springer, New Delhi, India.

Cai, X., G. Niu, T. Starman, and C. Hall. 2014a Response of six garden roses (rosa $\times$ hybrida $\mathrm{L}$.) to salt stress. Scientia Hort. 168:27-32.

Cai, X., Y. Sun, T. Starman, C. Hall, and G. Niu. 2014b. Response of 18 Earth-Kind ${ }^{\circledast}$ rose cultivars to salt stress. HortScience 49:544-549.

Cassaniti, C., D. Romano, and T.J. Flowers. 2012. The response of ornamental plants to saline irrigation water, p. 131-158. In: I. Garcia-Garizabal (ed.). Irrigation - water management, pollution and alternative strategies. InTech, Rijeka, Croatia. 28 Apr. 2019. <http://www.intechopen.com/books >.

Cavins, T.J., B.E. Whipker, and W.C. Fonteno. 2008 Pourthru: A method for monitoring nutrition in the greenhouse. Acta Hort. 779:289-297.

Dale, T.K., Y. Zeng, V.E. Stirm, R.J. Joly, and E.N. Ashworth. 2003. Photoperiodic regulation of a 24-kD dehydrin-like protein in red-osier dogwood (Cornus sericea L.) in relation to freezetolerance. Plant Cell Physiol. 44(1):25-34.
Davis, L., M. Sumner, C. Stasolla, and S. Renault. 2014. Salinity-induced changes in the root development of a northern woody species, Cornus sericea. Botany 92:597-606.

Day, S.D., J.R. Seiler, and N. Persaud. 2000. A comparison of root growth dynamics of silver maple and flowering dogwood in compacted soil at differing soil water contents. Tree Physiol. 20:257-263.

Dirr, M.A. 2009. Manual of woody landscape plants: Their identification, ornamental characteristics, culture, propagation and uses. 6th ed. Stipes Publishing Co., Champaign, IL.

Farooq, M., A. Wahid, N. Kobayashi, D. Fujita, and S.M.A. Basra. 2008. Plant drought stress: Effects, mechanisms and management, p. 153-188. In: E. Lichtfouse, M. Navarrete, P. Debaeke, S. Véronique, and C. Alberola (eds.). Sustainable agriculture. Springer, Berlin, Germany.

García-Caparrós, C., M.J. Romero, A. Llanderal, P Cermeño, M.T. Lao, and M.L. Segura. 2019 Effects of drought stress on biomass, essential oil content, nutritional parameters, and costs of production in six Lamiaceae species. Water 11(3):573

Gavlak, R.G., D.A. Horneck, and R.O. Miller. 1994. Plant, soil, and water reference methods for the western region. Western Regional Extension Publication (WREP) 125, Cooperative Extension, Washington State University.

Govahi, M., A. Ghalavand, F. Nadjafi, and A Sorooshzadeh. 2015. Comparing different soil fertility systems in Sage (Salvia officinalis) under water deficiency. Ind. Crops Prod. 74:20-27.

Grattan, S.R. and C.M. Grieve. 1999. Salinity mineral nutrient relations in horticultural crops. Scientia Hort. 78:127-157.

Grieve, C., L. Wu, L. Rollins, and A. Harivandi. 2008. Tolerance by landscape plants of salinity and of specific ions, p. 103-161. In: K. Tanji, S. Grattan, C. Grieve, A. Harivandi, L. Rollins, D. Shaw, B. Sheikh, and L. Wu (eds.). A comprehensive literature review on salt management guide for landscape irrigation with recycled water in coastal southern California. University of California-Davis, Davis, CA. 28 Apr. 2019. $<\mathrm{http}: / /$ www.salinitymanagement.org/>.

Havlin, J.L. and P.N. Soltanpour. 1989. A nitric acid and plant digest method for use with inductively coupled plasma spectrometry. Commun. Soil Sci. Plant Anal. 14:969-980.

Hinckley, T.M., F. Duhme, A.R. Hinckley, and H. Richter. 1980. Water relations of drought hardy shrubs: Osmotic potential and stomatal reactivity. Plant Cell Environ. 3:131-140.

Isaac, R.A. and W.C. Johnson. 1975. Collaborative study of wet and dry ashing techniques for the elemental analysis of plant tissue by atomic absorption spectrophotometry. J. Assoc. Off. Anal. Chem. 58:436-440.

Jones, H.G. 1993. Drought tolerance and water-use efficiency, p. 193-203. In: J.A.C. Smith and H. Griffiths (eds.). Water deficits plant responses from cell to community. BIOS Sci. Ltd., Oxford, UK.

Khayyat, M., A. Tehranifar, G.H. Davarynejad, and M.H. Sayyari-Zahan. 2016. Effects of $\mathrm{NaCl}$ salinity on some leaf nutrient concentrations, non-photochemical quenching and the efficiency of the PSII photochemistry of two Iranian pomegranate varieties under greenhouse and field conditions: Preliminary results. J. Plant Nutr. 39:1752-1765.

Konarska, A. 2011. Flower nectary structure in Cornus alba. Plant Syst. Evol. 291:1-6.

Liu, Q., Y. Sun, G. Niu, J. Altland, L. Chen, and L. Jiang. 2017. Morphological and physiological responses of ten ornamental taxa to saline water irrigation. HortScience 52(12):1816-1822. 
Maxwell, K. and G.N. Johnson. 2000. Chlorophyll fluorescence-a practical guide. J. Expt. Bot. 51:659-668.

Munns, R. and M. Tester. 2008. Mechanisms of salinity tolerance. Annu. Rev. Plant Biol. 59:651-681.

Mustard, J. and S. Renault. 2004. Effects of $\mathrm{NaCl}$ on water relations and cell wall elasticity and composition of red-osier dogwood (Cornus stolonifera) seedlings. Physiol. Plant. 121:265-271.

Mustard, J. and S. Renault. 2006. Response of redosier dogwood (Cornus sericea) seedlings to $\mathrm{NaCl}$ during the onset of bud break. Can. J. Bot. 84:844-851.

Naasz, R., J.C. Michel, and S. Charpentier. 2005. Measuring hysteretic hydraulic properties of peat and pine bark using a transient method. Soil Sci. Soc. Amer. J. 69:13-22.

Nemali, K.S. and M.W. van Iersel. 2006. An automated system for controlling drought stress and irrigation in potted plants. Scientia Horticulturae 110:292-297.

Niu, G. and R.I. Cabrera. 2010. Growth and physiological responses of landscape plants to saline water irrigation: A review. HortScience 45:16051609.

Niu, G., D.S. Rodriguez, and L. Aguiniga. 2007. Growth and landscape performance of ten herbaceous species in response to saline water irrigation. J. Environ. Hort. 25:204-210.

Niu, G., D.S. Rodriguez, and L. Aguiniga. 2008. Effect of saline water irrigation on growth and physiological responses of three rose rootstocks. HortScience 43:1479-1484.

Niu, G., T. Starman, and D. Byrne. 2013. Responses of growth and mineral nutrition of garden roses to saline water irrigation. HortScience 48:756-761.

Petropoulos, S.A., E. Levizou, G. Ntatsi, Â. Fernandes, K. Petrotos, K. Akoumianakis, L. Barros, and I.C.F.R. Ferreira. 2017. Salinity effect on nutritional value, chemical composition and bioactive compounds content of Cichorium spinosum L. Food Chem. 214:129-136.

Renault, S. 2005. Response of red-osier dogwood (Cornus stolonifera) seedlings to sodium sulphate salinity: Effects of supplemental calcium. Physiol. Plant. 123:75-81.

Renault, S. and M. Affifi. 2009. Improving $\mathrm{NaCl}$ resistance of red-osier dogwood: Role of $\mathrm{CaCl}_{2}$ and $\mathrm{CaSO}_{4}$. Plant Soil 315:123-133.

Rodríguez, P., A. Torrecillas, M.A. Morales, M.F. Ortuño, and M.J. Sánchez-Blanco. 2005. Effects of $\mathrm{NaCl}$ salinity and water stress on growth and water relations of Asteriscus maritimus plants. Environ. Exp. Bot. 53:113-123.

Sánchez-Blanco, M.J., S. Alvarez, A. Navarro, and S. Bañón. 2009. Changes in leaf water relations, gas exchange, growth and flowering quality in potted geranium plants irrigated with different water regimes. J. Plant Physiol. 166:467-476.

Sharpley, A.N., J.J. Meisinger, J.F. Power, and D.L. Suarez. 1992. Root extraction of nutrients associated with long-term soil management, p. 151-217. In: B. Stewart (ed.). Advances in Soil Science. Springer, New York.

Starman, T. and L. Lombardini. 2006. Growth, gas exchange, and chlorophyll fluorescence of four ornamental herbaceous perennials during water deficit conditions. J. Amer. Soc. Hort. Sci. 131:469-475.

Subbarao, G.V., N.H. Nam, Y.S. Chauhan, and C. Johansen. 2000. Osmotic adjustment, water relations and carbohydrate remobilization in pigeonpea under water deficits. J. Plant Physiol. 157:651-659.

Sun Gro Horticulture. 2019. Professional products. Agawam, MA. 28 Apr. 2019. <http://www.sungro. com/professional-products/all/>.

Sun, Y., G. Niu, and C. Perez. 2015. Relative salt tolerance of seven Texas Superstar ${ }^{\circledR}$ perennials. HortScience 50:1562-1566.
Sun, Y., G. Niu, J.G. Masabni, and G. Ganjegunte. 2018. Relative salt tolerance of 22 pomegranate (Punica granatum) cultivars. HortScience 53:1513-1519.

Taiz, L., E. Zeiger, L.M. Møller, and A. Murphy. 2015. Plant physiology and development. 6th ed. Sinauer Associates, Sunderland, MA.

Thomas, D.S. and D.W. Turner. 2001. Banana (Musa sp.) leaf gas exchange and chlorophyll fluorescence in response to soil drought, shading and lamina folding. Scientia Hort. 90:93108.

Voss, I., B. Sunil, R. Scheibe, and A.S. Raghavendra. 2013. Emerging concept for the role of photorespiration as an important part of abiotic stress response. Plant Biol. 15:713-722.

Wu, S., Y. Sun, G. Niu, L.G.P. Graciela, and C.R. Arturo. 2016. Responses of six Lamiaceae landscape species to saline water. J. Environ. Hort. 34:30-35.

Xu, W.Y., L. Sun, and L.Q. Mu. 2011. Adaptability of Cornus alba seedling under drought stress in highway greening. Appl. Mech. Mater. 9093:3262-3267.

Yokota, A., S. Kawasaki, M. Iwano, C. Nakamura, C. Miyake, and K. Akashi. 2002. Citrulline and DRIP-1 Protein (ArgE Homologue) in drought tolerance of wild watermelon. Ann. Bot. 89: 825-832.

Zhang, Z.X., D.F. Deng, W.J. Qi, S.S. Fan, C. Yue, J.G. Huang, and Y.L. Zhen. 2013. Botryosphaeria dothidea, the causal agent of a new stem canker disease of tatarian dogwood (Cornus alba) in China. Australas. Plant Pathol. 42(2):113-119.

Zhen, S.Y., S.E. Burnett, M.E. Day, and M.W. van Iersel. 2014. Effects of substrate water content on morphology and physiology of rosemary, canadian columbine, and cheddar pink. HortScience 49:486-492. 